\title{
From Eurocentric World Literature to Global World Literature*
}

\author{
Kim Jae-yong \\ Wonkwang University \\ heemin@wonkwang.ac.kr
}

\begin{abstract}
Editors' Note: Among the liveliest and most ambitious journals in world literary studies today is the biennial Korean journal Chigujŏk segye munhak (Global World Literature), edited by Kim Jae-yong. Professor of modern Korean literature and world literature at Wonkwang University in Iksan, South Korea. Kim is the author and editor or co-editor of numerous books on Korean and world literature, including Hyŏmnyŏk kwa chŏhang (Collaboration and Resistance, 2004), Segye munhak ŭrosŏ ŭi asia munhak (Asian Literature as World Literature, 2012), and Rat Fire: Korean Stories from the Japanese Empire (2013). The following essay, translated for JWL by John Kim, is an expanded version of Kim Jae-young's programmatic essay for his journal's first issue (Spring 2013), in which he sets out the rationale for the journal as a counter to the persistent Euro-Americancentrism of much world literary study, both in the West and in Asia itself. Genuinely global in its presentation of world literature, the journal is published in Korean and is designed for a broad scholarly and general readership in South Korea, providing a notable example of the contemporary development of world literary studies within a distinct national context.
\end{abstract}

\section{Keywords}

World Literature - Asian literature - Eurocentrism

\footnotetext{
* Translated by John Kim.
} 
Two hundred years after Goethe spoke of the passing of the age of national literature and the coming of the age of world literature, can we truly say that it has arrived?

When Goethe spoke those words, Europe was turning to Asia with particular interest. Of course, after emerging from the Middle Ages, Europe became interested, first and foremost, in Greek and Roman culture. The passionate intensity with which Europeans strove to make Greek and Roman culture their own is clearly seen in what is known today as the Renaissance. But in their attempt to usher in a new age by reinterpreting Greek and Roman culture, there was another thing they could not overlook: Asian culture. The abundant intellectual artifacts of Asian literature, which had been relatively neglected due to geographic separation, could no longer be ignored, as these works began to be introduced, here and there, into Europe. Europeans came to believe that by making Asian literary artifacts their own, they would ultimately be able to inherit the literary artifacts of all mankind. It was this intellectual fervor to which Goethe was indebted as he pored obsessively over European translations of Asian literature. He read through everything from the less distant Hebrew literature to the more distant Chinese literature. Deeply fascinated by Chinese literature, he realized that it was perhaps not all that different from European literature, and announced the dawn of a new era of world literature, one in which the whole spectrum of brilliant literature, East and West, could be beheld.

But soon after Goethe's proclamation, the winds of industrialization that swept across England and the Continent swept through the rest of the world as well, and any thought of Goethe's world literature disappeared in the blink of an eye. Europeans who had tasted the power of steamships and locomotives began to think of themselves as the center of the world and began to see the rest of the world as a pitiful existence in dire need of Civilization and Progress. They thought that European literature was world literature and that all other literatures were merely, and clearly, an inferior patois. Such a false notion was certainly internalized by the Europeans themselves, but what is even worse is that it started to be internalized by non-Europeans as well. Europeans endeavored to hold their literature up as a model for non-Europeans to follow, while non-Europeans disavowed their own literary traditions and put forth their best efforts to emulate the European literary tradition. Eurocentrism took the whole world by storm, and it remained unchallenged for more than a hundred years, until Asian and African intellectuals and writers began to contest it.

After World War II, as Asian and African nations began to free themselves from European colonialism, circumstances slowly started to change. After wit- 
nessing the atrocities perpetrated by European imperialism and seeing through the façade of Civilization and Progress, they were no longer captivated by the allure of regarding European literature as the sum total of world literature. At the same time, non-European writers, who were in a position not only to claim European literature as their own but also to create new kinds of literature, were producing literary works with intense zeal. As a result, it became increasingly difficult to support the notion that world literature was, in fact, European literature. As was certainly true for Asia, which already had a long written literary tradition, new literary works and writers appeared across Africa, which had had a tradition of oral literature. In particular, the new novels that swept across Latin America in the wake of the Cuban Revolution forcefully struck not only Europe but the entire globe as well.

The Euro-American literary discourse has not overlooked this tectonic shift in world literature and has responded swiftly, and no longer clings to the notion of calling European literature "world literature," as it had in the past. Instead, it has proactively drawn in literatures from places outside of Europe and institutionalized this practice under the name of "comparative literature" or "world literature." Even a glance at the latest publications of English-language anthologies of world literature will confirm the swiftness of its response. However, though the new way that the Euro-American literary establishment regards world literature has expanded its sources and subjects, it is still unable to escape the Euro-American-centric nature of its own perspective. Along with the swift Euro-American response, then, in spite of the good works that are being created in the non-west, the literary establishment has not been able to change the mold of world literature, because it lacks the base and the vision to actually bring these works fully into the realm of discourse.

It was not the case that Global World Literature just happened to come into existence. It was based on a forum on Asian, African, and Latin American literature that was hosted in Korea starting in 2007. There had been academic conferences for Asian and African literature prior to the fall of the Soviet Union, but because of the tensions between the Soviet Union and China, these conferences were embroiled in internal conflict, to the extent that they set up separate administrative offices in Egypt and Ceylon. These organizations existed in name only, and they disappeared as soon as the Soviet Union fell. Although they claimed to support Asia and Africa, in actuality they could not contain the voice of the non-west, and these groups that had begun with the start of the Cold War collapsed with the end of the Cold War. Moreover, they had ignored an important axis of the non-European world-Latin America.

Thinking that a new collaborative framework was needed, an Asian, African, and Latin American literature forum was organized in Korea. At this forum, 
writers who had come from non-western regions unanimously called for the creation of a journal that would go beyond Euro-American-centrism. However, they realized that if the journal were to handle only non-western literature, the exclusion of Euro-American literature would make the prospect of a truly global world literature rather difficult. So they decided to create a journal that would put western and non-western literatures together. As a result, the geographies handled by this journal span the five regions of Asia, Euro-America, the Middle East, Africa, and Latin America. Although the Middle East is not usually set apart from Asia and Africa, as it lies between the two continents, this journal recognizes the importance of the Middle East as an independent field and places it side by side with the other regions. And, despite the differences between Europe and North America, these two have been tied together around the single point of view called "the West." Doing this simultaneously shows the continuities and discontinuities between European and American literature while emphasizing the point that these two do not comprise the wholebut rather, an important piece — of world literature. Likewise, the reason why Global World Literature takes regional divisions so seriously is to reflect the situation after World War II, when literature in the non-west gained increasing dynamism, including the emergence of Latin American literature on the world stage as both participating in and yet distinct from Western culture in its European and North American manifestations.

Global World Literature is not like most other academic journals, as it features literary works alongside academic scholarship. Academic journals often do not carry literary works but mostly publish critical essays or scholarship, while literary magazines often do not carry critical essays or scholarship but only literary works. In contrast, Global World Literature includes both kinds of writing. The emphasis on putting literary works side by side with critical essays and academic scholarship in particular was important because until now, due to the hegemony of the theoretical framework of Euro-Americanism, there were not many critical or scholarly works that tried to overcome it. And because a discourse on henceforth overcoming Euro-Americanism became necessary, we have made a conscious effort to include these various kinds of writing. It is also due to this emphasis that the journal has undertaken the work of rediscovering and reinterpreting Asia's Rabindranath Tagore, Africa's Edward Wilmot Blyden, and Latin America's José Martí, as well as the Islamic modernist Jamal ad-Din al-Afghani. The decision to include literary works was to ensure that theoretical discussions would not take place in a vacuum, divorced from the support of real literary works. Today, we are witnessing an explosion of literary production in the non-west that we have not seen before, but many important literary works do not receive the theoretical attention they deserve and fade 
away. Within the discourse of world literature, the influence of western theory is still so strong that the creation of non-western literary works is not receiving proper attention. And so much effort is being put into introducing these literary works through translation, in the hope that from this perspective, a new discourse can arise from a foundation forged from translating controversial non-western writings.

Thus it was with the intention of being a non-western outpost capable of changing the landscape of this kind of world literature that the journal Global World Literature has ultimately been conceived. 